\title{
Research on Legal Management System of Foreign Enterprises
}

\author{
Gong Liuqing
}

Law School of Guangdong University of Finance and Economics, Guangdong, 510320

Keywords: legal affairs management; enterprises; corporate governance

\begin{abstract}
Modern legal affairs management of enterprises is an important system to achieve the goals of compliance management and risk management. Western countries such as America and Germany have deep understandings of importance of enterprises legal affairs management. It is necessary to further conduct research on enterprises legal affairs management models of large enterprises and transnational corporations in the western countries.
\end{abstract}

\section{Introduction}

Definition and Generation of Corporate Legal Affairs Management. Enterprise legal affairs management does not appear when the enterprise arises, but the enterprise develops to a certain stage of the system. Corporate legal affairs management in a narrow sense refers to legal affairs management system, organization, mechanism, culture, objectives and means, including consultation, negotiation, contract management, intellectual property protection, labor relations coordination, risk control, decision-making participation, litigation, corporate crisis handling and response, and the interaction between external lawyers. The legal affairs management of the enterprise is a dynamic process, which is continuously developed and perfected according to the business development of the enterprise. In a closed economy, enterprises have better control over their business environment, and all kinds of business risks can be solved quickly through non-institutional methods, so the demand for legal affairs management is relatively low. However, in an open competitive environment, enterprises control weaknesses of various risks, and therefore, various potential business risks need to be prevented and resolved through institutional measures. The management of legal affairs in modern enterprises came into being in this context. Enterprises through standardized contract management, the timely protection of intellectual property rights, the use of legal means to coordinate labor relations, through the Law Commission and other institutions to implement the risk control of enterprises, in the decision-making, litigation, corporate crisis and other aspects of standardized legal affairs management system and process, to achieve compliance management and risk management.

\section{The Development of Enterprise Legal Affairs Management}

Since the establishment of Legal Department of Standard Oil Company of New Jersey in 1882, the management of corporate legal affairs has a history of one hundred years. From small to large, from weak to strong and from naive to mature, it has always been developed and matured with the development and improvement of the modern enterprise system and has now become an important part of the modern enterprise system. As early as the 1920s and the 1930s, the United States General Motors Corporation established the legal department as early as 1921, and the legal department was directly under the leadership of the president. However, in the true sense of legal administration, it was established in the 1950s and 1960s. The establishment of legal affairs management institutions is generally established in the large corporations of the United States. The position of the general counsel is obviously improved. Most of them are vice-chairman or vice president. They are directly responsible to and report to the board of directors and the president. By the 1980s and especially into the 21st century, the negative effect of economic globalization is highlighted, the governance system in which the U.S. companies are proud of has been questioned. In order to improve the image of the enterprise, the United States should pay more attention to 
corporate compliance management, and a more important position in legal affairs management. In European countries, Germany pays more attention to the management of corporate legal affairs, Similar to the United States, the status of the legal affairs department is very high, this is related to Germany's strong industrial development. It can be said that the American model and the German model are typical examples of modern enterprise legal affairs management.

\section{The Management Mode of Enterprise Legal Affairs in Western Countries - Taking Large Enterprises and Transnational Corporations as Examples}

The management of legal affairs of large enterprises and transnational corporations in western countries will be evaluated and controlled in the form of legal affairs management from the day-to-day management of an enterprise to major projects according to their own business needs.

\subsection{Establishment of legal affairs management system with the core of general counsel}

The general counsel of multinational corporations in the United States is generally set at the top management level of a company, positioning in the senior vice president, with the chief financial Officer, vice president of human resources, sales Vice president and other senior executives, is one of the core departments of enterprises, responsible for the management of the company's legal affairs. Its main functions are: The first is to participate in the operation and management of the company, participate in all important meetings of the company, and participate in the decision-making of all major matters related to the company's law, finance, strategy, sales, operation and assessment. Second, responsible for compliance management. The compliance management of American companies mainly includes three aspects. On the one hand, it studies and masters all the new laws, regulations and policies formulated by the state, adjust all decisions of the company and ensure that the company's behavior complies with the laws and regulations of the state. On the other hand, to formulate internal company rules and regulations and ensure that every employee knows the company rules, guarantee the effective implementation of internal regulations. The third is responsible for government public relations. It is generally accepted by large US corporations that government regulation of enterprises is often achieved through the formulation of laws, policies and other measures. Therefore, the coordination between the government and the government is mainly led by the general counsel, and the legal department conducts specific work. The fourth is responsible for intellectual property rights. Big American companies generally take intellectual property rights as an important part of the legal department, led by the general counsel of the company. The fifth is responsible for the company's internal investigation. In the United States, large enterprises usually have internal investigation agencies. Once they have internal and external reports they must initiate internal investigation. Sixth, leading the company legal team. To lead the legal department to carry out daily affairs such as drafting, contract management, litigation and external lawyer selection, which is basically the same as the daily duties of the general counsel of China's central enterprises. A PwC survey shows that the general counsel for all large and medium-sized corporate law offices in the United States is involved in the formulation of corporate strategy and full business plans as well as regular business analysis sessions.

\subsection{The establishment and management of the internal legal department}

First, the establishment of the internal legal department. Most of the general legal department is set at the senior management level of the enterprise, and the overall legal affairs management of the enterprise is implemented under the leadership of the general counsel. The legal affairs departments of the U.S. corporations have multiple legal departments according to the division of business. Since the early expansion of the overseas market in Germany, the enterprise groups have tended to establish subsidiaries in the relationship of entrusted cooperation. Under the control of the parent company, the legal department conducts legal affairs management for the parent company and its subsidiaries. Under this relationship, the subsidiary enjoys full autonomy within the scope of the authority to agree with the parent company. Second, the mode of legal affairs management. The legal affairs of large American corporations are divided into centralized management, decentralized 
management and matrix management. System of centralized management, also known as the longitudinal mode, set up a company in headquarters functions more comprehensive legal affairs department, subsidiaries and branch office of legal counsel sent directly by the headquarters, the regional legal department report directly to the head office and shall be responsible to the head office, and is not responsible for district general managers. This model is suitable for large enterprises with large business relationship and total subsidiaries. Decentralized management, in addition to the establishment of the legal department at headquarters, in the subsidiaries and branch offices set up legal affairs. The legal affairs department of the regional company is responsible for the regional company and is also responsible for the headquarters of the company. However, the company headquarters still have the right to manage the major issues of regional companies. Matrix management usually is vertical and horizontal combination, and vertical-based. Matrix is to manage the legal affairs in a project manner, and to guide the overall project work in a certain department. The advantage is that legal affairs management is flexible and convenient, but the disadvantage is that it is difficult to form stable legal affairs management mechanism.

\subsection{Perfect legal affairs management system and process}

First of all, from the point of view of the content of the legal affairs management, the content of the national legal affairs management approximation, classification of roughly similar to Japanese companies of justice legal affairs management can be divided into legal prevention and the processing of individual problems and disputes, and strategic legal three parts. Secondly, legal personnel (including legal advisors) participate in the rights and methods of enterprise operation and have perfect institutional guarantee. The company's legal personnel participate in the business operation of the authority and the way is also different under different legal affairs management mode. The company's legal affairs are comprehensively managed. In the centralized management mode, the company headquarters under the leadership of general counsel, the company's legal affairs conduct a comprehensive management. The general counsel is responsible for regional legal affairs, and the head office is responsible for matters relating to major companies. In the decentralized management mode, regional legal affairs are handled by the regional legal department. The head office will not interfere with the legal affairs in the area when no major corporate matters are involved. However, the legal affairs department of the head office will come forward coordinate decisions when it is necessary to coordinate the head office and regional legal affairs.

\section{Analysis of Legal Management Experience in Western Countries}

It is a common practice for western enterprises to carry out legal affairs management within enterprises. In terms of internal governance, the legal department of enterprises in the western countries is an important department of compliance management of enterprises. Regardless of the form of property right, the management of enterprises through legal forms is the common practice of modern enterprises. Through the method of legal affairs management, the enterprise clarifies the work authority and process of the legal department of the enterprise, makes the corporate behavior more compliant and plays a good governance role in the enterprise management problems such as "insider control". It can be said that the legal affairs management of an enterprise can reduce any business conduct of an enterprise and indirectly play a role of supervising an enterprise and is a powerful supplement to external supervision. Through both the external and internal modes, the state-owned enterprises in the western countries are very standardized in terms of compliance and play an important role in the development of the state-owned economy, in cultivating the competitiveness of enterprises and in the compliance operation within enterprises. In particular, the management of compliance within the enterprise through legal affairs management is the characteristic of the normative operation of enterprises in western countries. This characteristic has a positive influence on the global competitiveness of western enterprises, which is an endorsement of enterprise credit, and indirectly promotes the operation of enterprises. Although the compliance 
operation of enterprises in western countries will bring about certain costs, taking into account the long-term development and operation of enterprises, the compliance of enterprises and the management of legal affairs are the future directions for the development of enterprises.

\subsection{Mixed-ownership firms are more reliant on legal affairs}

An important trend in the development of state-owned economy abroad is the decreasing number of government-owned enterprises and the increasing number of "government-civilian mixed enterprises". In the mixed enterprise, the state-owned capital is mainly the government holding enterprises, while the private capital is mainly the government's participation in enterprises. The rapid development of such hybrid enterprises is not only due to the fact that the functions of the state economy can be brought into play better through the capital integration and the control power of the state capital can be enhanced. Moreover, the ownership structure of the moneylender formed by capital integration can help shape independent corporate property rights, to achieve the conversion of state-owned enterprises operating mechanism. Under the trend of mixed economy, corporate legal affairs management ways of management is the condition of this kind of enterprise management must in order to guarantee the rights and interests of the parties to get fair treatment, so in the tide of mixed ownership, legal affairs management method of mixed ownership enterprises become the west necessary management style. There are many conflicts of interests among all parties in the mixed ownership enterprises. The traditional corporate governance model can not effectively resolve the disputes. However, the management of the legal affairs of the enterprises can resolve the disputes among the enterprises in daily operation and thus become a trend of the management of the mixed ownership enterprises. Under the tide of deepening the reform of the economic system in our country, the state-owned economy has achieved leapfrog development by various means. One of the major forms is the system of mixed ownership. However, all parties involved in the mixed ownership system will face the same problems faced by the enterprises in the mixed economy in the western countries in the course of their business operations. The solution is also a way of legal affairs management. Therefore, under the same economic background, legal affairs management has become a necessary mode of enterprise management for the state-owned enterprises in the western countries.

\subsection{The model of enterprise culture affecting the enterprise legal management}

In a variety of different institutional environments for the management of corporate legal affairs, the inherent impetus of institutional constraints comes from the corporate culture, which is developed by a country's enterprises in the country's economic environment and institutional environment, which adapts to the country's economic and institutional environment Therefore, the management of legal affairs of state-owned enterprises in various countries is the result of adapting to the economic environment and institutional environment of the country. When learning from the experience of other countries, it is imperative to consider the preconditions for the system to learn from and to make advanced systems suitable for the transformation of their own environment effective reference. In the United States, state-owned enterprises and large-scale enterprises are market-oriented. All types of systems and management models take this as their core. Their daily operation and management adhere to competition as a means. Regardless of the type of enterprises, competition is the means and benefits the purpose, legal management system is also built around the core purpose of business and with the United States institutional background and economic environment to adapt.

\section{Conclusion}

Legal affairs management is a modern enterprise in developing nots allow to ignore to link, enhance the legal affairs management ability is the premise of enterprise to realize the legal affairs management in the enterprise management level of some of the problems and limitation in the inhibitors of ascension can only suit the remedy to the case, identify the reasons of the obstacles to solve the problem. 


\section{References}

[1] Luo Yan, Legal management of American enterprises, petroleum economics,3.(1999).

[2] Ye Xiaozhong, Chinese corporate law observation, Law Press China,52. (2014).

[3] Practical Ideas for Managing Your Law Department's Performance, in Perspectives On Corporate Legal Management 1, (Price Waterhouse LLP, ed. Winter 1995).

[4] Ren Weilin, Study on control mode of parent and subsidiary companies of state-owned enterprises, Doctoral thesis of Wuhan University. (2012).

[5] John C Coates, Michele M DeStefano, Ashish Nanda \& David B. Wilkins, Hiring Teams, Firms, and Lawyers: Evidence of Evolving Relationships in the Corporate Legal Market, 36 LAW \& SOC. INQUIRY 999, 1006(2011).

[6] George P. Baker \& Rachel Parkin, The Changing Structure of the Legal Services Industry and the Careers of Lawyers,84 N. C. L. REV. 16345,1654(2006). 